Canadian University Music Review

Revue de musique des universités canadiennes

\title{
Polarity in Schubert's Unfinished Symphony
}

\section{David P. Schroeder}

Numéro 1, 1980

URI : https://id.erudit.org/iderudit/1013733ar

DOI : https://doi.org/10.7202/1013733ar

Aller au sommaire du numéro

Éditeur(s)

Canadian University Music Society / Société de musique des universités

canadiennes

ISSN

0710-0353 (imprimé)

2291-2436 (numérique)

Découvrir la revue

Citer cet article

Schroeder, D. P. (1980). Polarity in Schubert's Unfinished Symphony. Canadian University Music Review / Revue de musique des universités canadiennes, (1),

22-34. https://doi.org/10.7202/1013733ar

All Rights Reserved (C Canadian University Music Society / Société de musique des universités canadiennes, 1980
Ce document est protégé par la loi sur le droit d'auteur. L'utilisation des services d’Érudit (y compris la reproduction) est assujettie à sa politique d'utilisation que vous pouvez consulter en ligne.

https://apropos.erudit.org/fr/usagers/politique-dutilisation/ 


\title{
POLARITY IN SCHUBERT'S UNFINISHED SYMPHONY
}

\author{
David P. Schroeder
}

It is a well-known fact that the years 1818 to 1822 were difficult ones for Schubert as a composer of instrumental music. At no time in his career did he have as much trouble getting instrumental compositions beyond the sketch stage and this is particularly true of the symphony. The suggestion has been put forward that his indecisiveness concerning instrumental and especially symphonic writing at this time was the result of his having to cope with the long shadow cast by Beethoven (Chusid 1968:9-10). While this undoubtedly was a factor, another important side to the problem has been largely ignored, and this concerns the much more intimate issue of what the composer hopes to accomplish with a symphony. With the Unfinished Symphony, it had been about four and a half years since Schubert had completed a symphonic movement, and those years saw not only the desire on his part to create a grand symphony but also a spiritual change which was to shape the nature of the symphonic content. This work marks a significant change in Schubert's approach to the symphony, as the sketch symphonies of the years preceding it appear to be unsuccessful efforts in realizing the conception which he was gradually envisaging. While he failed to achieve it in instrumental works before 1822, his new approach can be observed taking shape in other creative activities before that date, and the parallel between the achievement of the Unfinished and the genesis of the idea in these activities is remarkably close. The importance of the Lied to Schubert cannot be doubted, and the consistency with which he wrote songs throughout his career allows them to be taken as a type of sounding board of his musical and spiritual ideas at any given time. It is, in fact, in the activity of 
writing songs that one can see the discovery of the spiritual, musical, and dramatic principles which gave rise to the Unfinished.

In the two years immediately preceding the Unfinished, one finds a notable inclination in Schubert's songs. No single poet held a place comparable to Goethe in the composer's estimation, and the particular Goethe texts which he selected in the first half of 1821 may give some indication of the direction in which he was moving. The noteworthy texts from this time are taken from Goethe's Der West-östliche Divan ("Versunken," "Suleika I," "Suleika II" and "Geheimes"), Wilhelm Meister ("Mignon I" and "Mignon II") and a separate poem, "Grenzen der Menschheit." Through his career, Goethe gradually developed a notion of "polarity," "the belief that the nature of Man and of the universe (of which man was, for him, a microcosmic image) is formed of two 'polar' opposites, and that the task of wisdom is to bring these opposites into unity and harmony" (Gray 1967:40). In Der West-östliche Divan (1819), a mature work which has belatedly been recognized as one of Goethe's greatest, the theme of polarity comes to its full realization. This is first of all apparent in the attempt to combine East and West while allowing each to preserve its essence, providing a unity in duality. The work consists of lyrics organized into a cycle of twelve books, and the various poems are "both serious and ironic; both intellectual and emotional; the speaker is both Hatem and the 'real' Goethe; the love celebrated here contains happiness and resignation" (Hatfield 1963:115). Another significant part of the duality of Der West-östliche Divan is its dual authorship; some of the lyrics, such as those spoken by Suleika, were written by Marianne von Willemer. Goethe, nearing the age of seventy at this time, developed a relationship with her which started as something playful but became very serious. In spite of their strong love, the relationship remained Platonic, and some of the duality in this work could stem from "the paradox of a love which is requited but not fulfillable" (Hatfield 1963:115). Within the work, Suleika stands as a representation of perfect beauty, and in the poet's love for her, no distinction is made between the real woman or an illusory image of her. But polarity is not simply a literary device. Its embodiment in literature points to fundamental matters of existence. Taken to its ultimate end, as seems to be the case here and in other works such as Faust, Goethe appears to be putting forward the notion 
that one must accept both good and evil as equal forces, meaning that evil must be reconciled as belonging to the general order of things (Gray 1967:234-35).

In Wilhelm Meister, the idea of polarity is also present as the main character attempts to reconcile his two conflicting sides. In part, the possibility of a fusion of opposites is realized in the character Mignon who is always mysterious and is also hermaphroditic, referred to by Goethe as both "he" and "she." Her mysteriousness prevents the discovery of her full significance but it is probable that Goethe envisaged her as a symbol of the unification of the opposite sides of the self, something which remained one of the poet's personal aims throughout his life (Gray 1967:187-89). Mignon, it is eventually discovered, is the child of the Harper (whose three songs Schubert had set in 1816-D.478-80). In contrast to Mignon, the Harper has suffered as a result of opposites and has found no underlying unity: in his own words, "I am entitled to speak, for I have suffered as few men have, from the supreme, sweetest exaltation to the most terrible deserts of helplessness, vacuity, annihilation and despair, from the loftiest intimations of superterrestrial beings down to the most radical disbelief, to disbelief in myself" (Quoted in Gray 1967:187-88). The attempt to bring opposites into a coexistence pervades the work at all levels and it is also apparent that Goethe sees this as a means for the betterment of mankind. Wilhelm is occasionally confronted by mysterious strangers who offer advice and guide the course of his life. They prove to be members of a type of Masonic society known as the Company of the Tower and it is noteworthy that Goethe was a Freemason most of his life. The notion of finding a higher unity which allowed the coexistence of opposites was fundamental to Freemasonry and can be seen in such practical matters as the fact that Freemasons not only admitted members of different religious denominations but encouraged members to practice the religion of their choice. Human conflicts were recognized as inevitabilities, and a genuine sense of unity was seen as being able to transcend these. ${ }^{1}$ Freemasons believed it was their responsibility to spread this idea and the fact that so many writers and musicians of the late eighteenth and early nineteenth centuries were Freemasons attests to the compatibility that artists saw between their artistic and dramatic aims and Masonic ideology. 
The song "Grenzen der Menschheit," composed by Schubert immediately prior to "Suleika II," is the setting of a much earlier poem by Goethe (1779), but, along with "Gesang der Geister" 2 and "Mahomets-Gesang," 3 is representative of Goethe's early exploration of the theme of polarity. The polarity is not necessarily contained within a single poem but can exist in a comparison of different poems. The portrayal of the Supreme Being, for example, can be contradictory in different poems. In "Gesang der Geister" Nature plays a beneficent role whereas in "Grenzen der Menschheit" the gods are mere observers of the drama of men rising briefly and then sinking eternally. And within the poem "Grenzen der Menschheit," logical sequence is very often lacking. Goethe begins by describing poets' devotion to the Heavenly Father and states that men should not attempt to compare themselves with the gods, but concludes by making the comparison, asking in what ways the gods can be distinguished from mortals. The fact that the gods merely watch as men rise and sink in an endless chain is hardly cause for the "filial shudders true in my breast" (Zeydel 1955:65) expressed in the first verse. It is possible that Goethe was becoming so consumed by the idea of polarity that his expectation of opposition and contradiction as an essential part of life was encroaching on his own sense of logic (Gray 1967:42-43).

Any attempt to find biographical verification for Schubert's interest at this time in Goethe's theme of polarity would be highly speculative, although in considering the various facets of Schubert's life, it is not difficult to see possibilities. His "Allegorical Tale" of 1822 and entries in his diaries in 1816 and 1824 show that paradox was by no means a foreign idea (Deutsch 1946:226-28, 70-71, 336-37). This concerns larger archetypal matters such as a paradoxical relationship between life and death, and also the impossibility of people reaching each other in human relationships or the connection between art and suffering. It could, of course, be argued that his darker comments of 1824 were the result of his illness which followed the Unfinished but these remarks seem to be more the result of continuous experience than a single event. Whatever the parallels with his life may have been, he did concentrate his efforts early in 1821 on poetry in which polarity was the overriding theme, and his new approach in the first movement of the Unfinished Symphony is one in which opposing forces are 
engaged in complex relationships. The connection between the Goethe songs and the Symphony is made stronger by the fact that certain musical similarities can be observed. ${ }^{4}$ Of the songs cited, the key of B minor occurs with some consistency, being the key of "Mignon I," "Mignon II," and "Suleika I." One writer who draws a parallel is Alfred Einstein, pointing out that "Suleika I" is "not only in B minor, but also anticipates the rhythm and figuration of the beginning of the "Unfinished'-so literally that the underlying connection can hardly be denied" (Einstein 1951:219-20). Other parallels can be found and tonal relationships can be important here. As Tovey points out, Schubert's use of the submediant key rather than the relative major for the second group of the first movement of the Unfinished is unique in his sonata form movements (Tovey 1949:150). The only modulation away from B minor in "Mignon I" is also to the submediant, and it seems not without significance that this occurs at the point of exchange between darkness and light, emphasizing the relationship of these archetypal opposites.

A similar tonal relationship exists in "Grenzen der Menschheit," in this case establishing a powerful duality which creates a musical polarity and anticipates the Unfinished. The introduction to this song is symphonic in scope, full of ambiguity as it neither begins nor quickly settles in the home key of E major. The tonal areas $\mathrm{E}$ and $\mathrm{C}$ develop a relationship in this song, and these are linked by $B$ which is the dominant of one and leading tone of the other ( $F$ sharp will be seen to have a similar function in the Unfinished). That the "bridge" note B is of the greatest importance can be seen in the fact that it is the first note of the song, where it unexpectedly functions as a leading tone. The cadential pattern of measures 5-6 suggests that the $B$ of measure 6 should be a dominant, but now it becomes an even more emphatic leading tone.

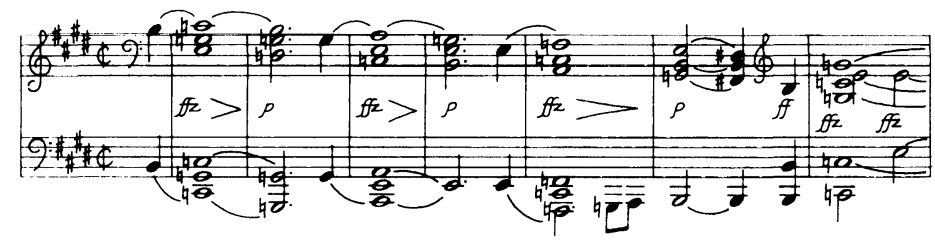

Example 1. Schubert: "Grenzen der Menschheit" (1821), mm. 1-7 
The listener must wait until measure 19 to hear B functioning as a true dominant. The E-C relationship continues to be a factor as the instrumental passage ( $\mathrm{mm}$. 49-52) linking the first two verses leads from $E$ to $C$. Throughout the song, $B$ continues to be a type of pivotal note, having the ability to lead in different directions. But curiously, the final four measures of the song, which are instrumental, contain a plagal rather than perfect cadence, and $B$ is therefore absent except as a part of the final $\mathrm{E}$ major chord. In the penultimate chord, a first inversion of the subdominant, the third degree is lowered to $\mathrm{C}$ natural, and, therefore, the final two chords again offer a strong C-E relationship. In this song, then, Schubert builds a sense of duality through an ambiguity-stability relationship, the key of E providing the stability and the tonal ambiguity being generated by $C$. B functions as a type of unifying agent, but at the same time, its intervallic connection with $E$ and $C$ supports the sense of duality as the perfect fifth offers stability while the semitone generates ambiguity. The unity is one in which opposites are able to coexist.

The Unfinished, as different as its conception is from earlier symphonies, did not originate in a vacuum. In "Grenzen der Menschheit" Schubert presented the kernel of the musical and dramatic problem in the introduction, and in the Unfinished, one cannot doubt that the first eight measures are of the greatest possible importance. ${ }^{5}$ The dynamic markings and instrumentation here seem designed to sharpen the listener's awareness of this passage (and they must also attest to Schubert's belief in the goodwill of his potential audience). In this passage, one finds a type of musical epigram which contains the polarities that will give rise to the intense drama of this movement, although the actual nature of the polarities is not readily apparent but only gradually becomes evident throughout the movement. ${ }^{6}$ The fact that these eight measures are often improperly phrased in performance has drawn notice more than once. Schubert's phrasing is essential to his purpose. The outer notes of each unit are very important and the correct phrasing is necessary for the point to be made. The intervallic movement is always that of a third: B-D, B-G, and D-F sharp (Ex. 2). Within this, other relationships can be observed, although their significance will not become apparent until later. In the first two phrase units, B-D and B-G form the outline of a $G$ major triad, and both the note $G$ and the key of $G$ will prove to be of 


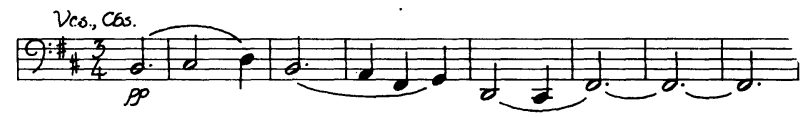

Example 2. Schubert: Symphony in B Minor ("Unfinished) (1822). I: Allegro moderato, mm. 1-8.

primary importance to the exposition. Against this, F sharp is sustained for three bars, and $F$ sharp, the dominant, is also the leading tone of $G$. Beside the series of thirds, then, a semitone emerges, which may be no more than subliminal here but ultimately proves to be a major force.

As the movement progresses, these relationships gradually begin to make themselves felt and the first instance of this occurs as early as measure 10. In the final half beat of that bar, the $C$ sharp and $E$ in the upper strings suggest a dominant seventh, but instead of an F sharp in the lower strings, there is a $G$, which is in a semitone relationship with the expected note and a third relationship with the ostinato $B$.

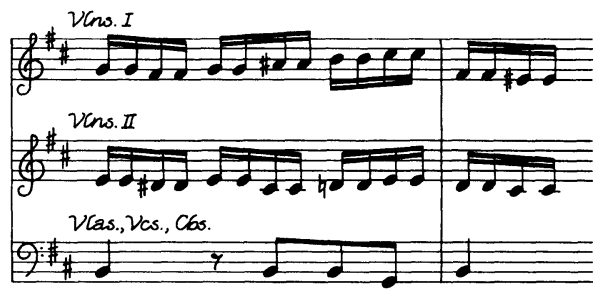

Example 3. Symphony in B Minor, I, mm. 10-11.

The unexpected appearance of $G$ at this point is the first mild suggestion of its importance. When a strong dominant occurs, first at measure 20 and later at measure $29, G$ is present as the top note of the chord in each case. The dominant ninth can simply be taken for the color it provides, but with these chords, emphasized by forzato markings, there is also the possibility of hearing the relationship of the top and bottom notes ( $G$ and $F$ sharp).

The appearance of the key of $G$ at the beginning of the second group (m. 42) comes as a surprise but some clarification is now shed on the first four measures of the work. The previous section ends in $B$ minor and the transition to $G$ is brought about by way of $D(\mathrm{~mm}$. 38-41). At the end of the exposition, a fairly direct reference is made to the opening eight measures of the 
work. The motion stops at measure 104, and as unexpectedly as $G$ had entered at measure 42 , B returns at this point, accented and fortissimo. As the B undergoes a decrescendo in the winds, the pizzicato strings answer at a pianissimo level with $G, F$ sharp and D (semitone-third): the opening epigram is now reduced (in different order) to its structural notes.

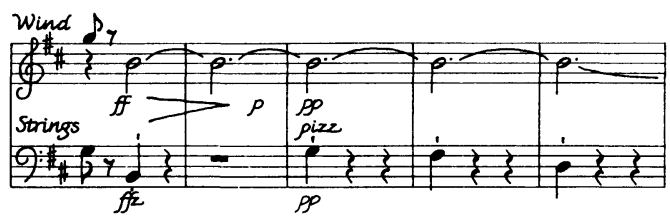

Example 4. Symphony in B Minor, I, mm. 104-08.

The development wastes no time in getting on with the thirdsemitone relationship. After a partial return of the opening figure, now in E minor, a canonic exchange begins at measure 122 , each unit made up of an ascending third followed by a descending half step.

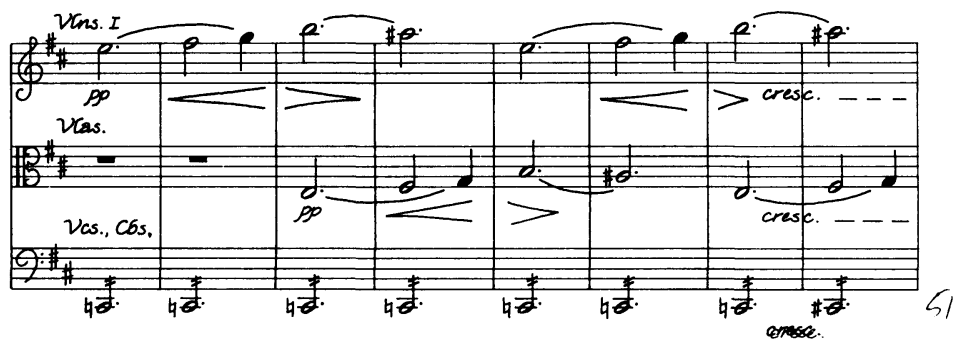

Example 5. Symphony in B Minor, I, mm. 122-29.

Also begining at this point, the cellos and basses carry on a separate activity, moving chromatically from $C$ to $F$ sharp. A pedal $\mathrm{F}$ sharp is then sustained for just over eleven measures (mm. 134-45) with no hint of dominant function. The predominant thematic activity above that is the outline of the third. This is followed by a new section of potential resolution and tension in which two cadential patterns fail to resolve but are met with diminished chords that are dynamically contrasted in the greatest possible way. By measure 170, expectation has been reversed so that the now expected diminished chord is replaced by a resolution. The "resolution" is, in fact, a return of the opening passage of the work, now in 
unison in almost the full orchestra and also dynamically contrasted with the beginning of the work in the greatest possible way. Following the brief excursion in $\mathrm{E}$ minor, the development goes on to generate considerable tension, with the tonic preparation ( $F$ sharp beginning at measure 202) immediately preceded by eight measures built on a pedal G. Just before the beginning of the recapitulation, the problem is again presented, now very gently in the flute.

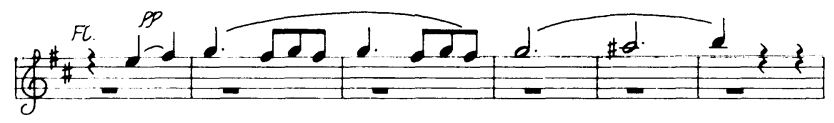

Example 6. Symphony in B Minor, I, mm. 213-18.

Starting on E, the line moves up a third to G, oscillates between $\mathrm{G}$ and $\mathrm{F}$ sharp for two bars and then moves up a third to the tonic.

Since stability is desired at the beginning of the recapitulation, it should now come as no surprise that this section omits the first eight measures which were seen to contain the tension-generating forces. The main changes in the recapitulation are tonal ones with the reappearance of $E$ minor at measure 231 , a second group in D major and a return to $B$ (this time $B$ major) for the closing theme. Aside from these, the second theme is extended an extra four measures, delaying the measure of silence and forte chords in a way that may for a moment suggest to the listener that the tension has been removed. Tension, however, is not removed, and the fact that the recapitulation reiterates both the stability and tension of the exposition suggests that resolution is not about to occur here. Rather, the recapitulation seems to represent a type of immutability, an affirmation of the ubiquitous nature of opposites and conflict.

Since the recapitulation has not provided a conclusion, the coda is given the function of drawing things together and making a final statement. A relationship can be observed in this movement between motivic material and harmonic or tonal events. The intervallic relationships of the first eight measures contain the kernel of both the stability and the tension of the movement and these are realized in motivic and tonal relationships. The end of the recapitulation, like that of the exposition, presents the four important notes (B, G, F sharp, and D), allowing one to reflect on the various ways in which these have 
interacted. Having omitted the original eight measures at the beginning of the recapitulation, Schubert now presents them in their original state. This exact return of the beginning epigrammatic part of the work in a sense places the coda outside the discursive portion of the movement. These eight measures originally stood as a type of compressed commentary on things to come, and the coda also functions as a critique. The harmonic tension which has continued until the coda is now absent as harmonic stability becomes firmly entrenched. Before the original eight-measure statement is completed, the winds turn the $\mathrm{F}$ sharp into a dominant chord, leaving no doubt as to its function. This stability suggests that some type of resolution has been found, but in order to see the full picture, thematic material must also be taken into account. Immediately after the opening statement, the upper strings recall the beginning of the development, at which point a passage occurred (Ex. 5) which had placed the third and semitone together and had been canonically expanded.

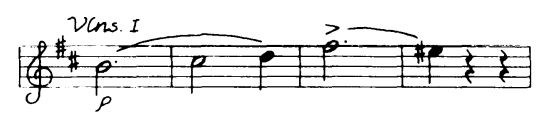

Example 7. Symphony in B Minor, I, mm. 338-41.

The development, of course, had gone on to generate a high degree of tension, and the reflection here on the tension-creating forces would seem to suggest that they have not disappeared. This point is then reaffirmed as the semitone is incessantly repeated in the whole orchestra in measures $340-47$, building dynamically and accelerating in pace, followed by a similar treatment of the third in measures 352-63 (Ex. 8).

By presenting the semitone and third separately in these large blocks, the composer seems to be emphasizing their polar character. In the end there is no real synthesis but rather the opposing forces are placed side by side in a way that they may be seen as being compatible.

Not unlike Goethe, Schubert's view of existence at this time was shaped by an understanding of polarities. His new conception of the symphony was one in which the symphony became a much closer reflection of matters of existence, moreso than a stylistic change intended to bring his symphonic works in line with those of another composer. ${ }^{7}$ The particular view of 

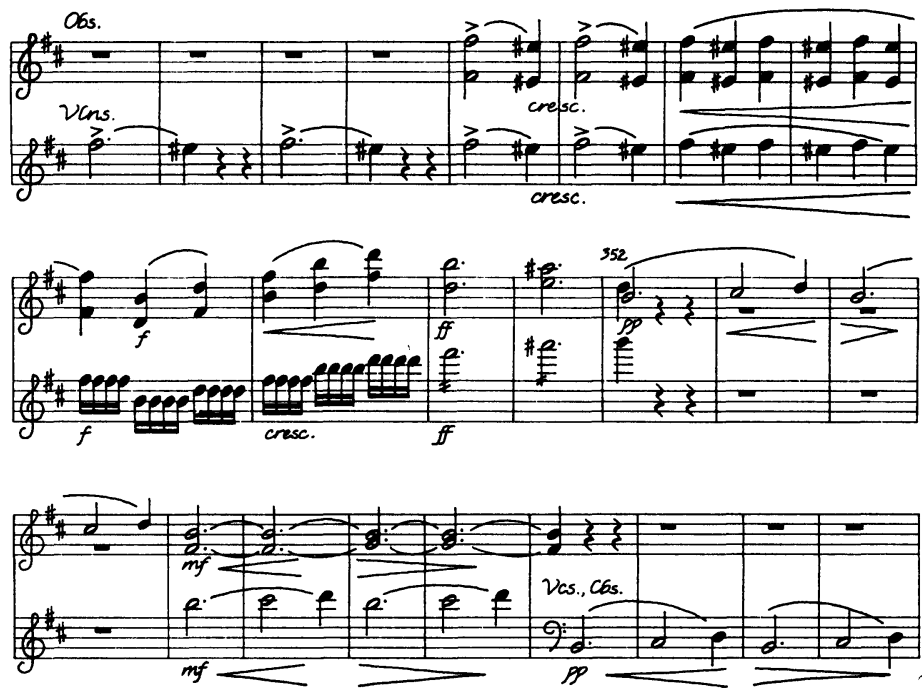

Example 8. Symphony in B Minor, I, mm. 340-63.

existence which Schubert shared with the greatest minds of his generation was on the one hand a matter of great intimacy since his own inner peace was very much at issue. But also, like his contemporaries who shared the view, there was a sense of responsibility to society in that the realization of how opposites can coexist without causing disintegration should be shared with all. In a musical work this coexistence could be demonstrated better than by any other means, and the symphony, intended as it was for large audiences, became the ideal vehicle. The fact that the Unfinished was not performed until 1865 should not detract from the possibility that Schubert's new conception of the symphony may have been related to a new attitude on his part to his audience. 


\section{NOTES}

1. This view is strongly advocated by Gotthold Lessing in his Masonic work Ernst und Falk. See Allison 1966:137-39.

2. Set by Schubert for Male Voice Octet with string accompaniment (D. 704) and Male Voice Chorus with pianoforte accompaniment (D. 705) in December 1820, and again for Octet, four tenors and four basses, with accompaniment for string instruments (D. 714) in February 1821.

3. A fragment for a male voice (D. 721) written in March 1821. According to Deutsch, the fragment of March 1817 (D. 549) for a female voice was probably completed.

4. It is also noteworthy that some of these songs were very much on Schubert's mind late in 1822. On 7 December 1822, he informed Joseph von Spaun that along with three songs dedicated to him would be issued the three songs of the Harper, "Suleika," and "Geheimes." See Deutsch 1946:247-49.

5. A fact to which others would certainly attest. See Griffel 1975:252.

6. By the end of the exposition the polarities have become fairly evident, and the practice of omitting the repeat of the exposition in performance deprives the listener of the opportunity to reaffirm the presence of the polarities in the first eight measures.

7. A strong case could be made, however, for an awareness on Schubert's part of Beethoven's use of the symphony as a means for disseminating ideas which could contribute to the betterment of mankind. See Downs 1970:585-604. 


\section{REFERENCES}

ALLISON, H.E.

1966: Lessing and the Enlightenment. Ann Arbor: University of Michigan Press.

CHUSID, M.

1968: "The Historical Background," in Franz Schubert: Symphony in B Minor ("Unfinished"). New York: W.W. Norton.

DEUTSCH, O. E.

1946: Schubert: A Documentary Biography. Translated by Eric Blom. London: J.M. Dent.

DOWNS, P.G.

1970: "Beethoven's 'New Way' and the Eroica," The Musical Quarterly, LVI/4, 585-604. Reprinted in Lang, Paul Henry, ed., 1971: The Creative World of Beethoven. New York: W.W. Norton.

EINSTEIN, A.

1951: Schubert. Translated by David Ascoli. London: Oxford University Press.

GRAY, R.

1967: Goethe: A Critical Introduction. London: Cambridge University Press.

GRIFFEL, L.M.

1975: "Schubert's Approach to the Symphony." Unpublished Ph.D. dissertation, Columbia University.

HATFIELD, $\mathrm{H}$.

1963: Goethe: A Critical Introduction. Cambridge, Mass.: Harvard University Press.

TOVEY, D.F.

1949: "Tonality in Schubert," in Essays and Lectures on Music. London: Oxford University Press.

ZEYDEL, E.H.

1955: Goethe, the Lyricist. 2nd edition. Chapel Hill: University of North Carolina Press. 